Article

\title{
Diphenyl Ethers from a Marine-Derived Aspergillus sydowii
}

\author{
Ya-Nan Wang 2,+田, Yan-Hua Mou ${ }^{1,+}$, Yu Dong ${ }^{1,2,+}$, Yan Wu ${ }^{2}$, Bing-Yu Liu ${ }^{2}$, Jian Bai ${ }^{2}$, \\ Dao-Jiang Yan ${ }^{2}$, Le Zhang ${ }^{2}$, Dan-Qing Feng ${ }^{3}$, Yue-Hu Pei ${ }^{1, *}$ and You-Cai Hu ${ }^{2, *}$ (D) \\ 1 School of Life Science and Biopharmaceutics, Shenyang Pharmaceutical University, Shenyang 110016, China; \\ mu_hua_jj@sina.com (Y.-H.M.); allenn7@foxmail.com (Y.D.) \\ 2 State Key Laboratory of Bioactive Substance and Function of Natural Medicines, Institute of Materia Medica, \\ Chinese Academy of Medical Sciences and Peking Union Medical College, Beijing 100050, China; \\ wangyanan@imm.ac.cn (Y.-N.W.); wuyan@imm.ac.cn (Y.W.); liubingyu@imm.ac.cn (B.-Y.L.); \\ baijian@imm.ac.cn (J.B.); yandj@imm.ac.cn (D.-J.Y.); zhangle@imm.ac.cn (L.Z.) \\ 3 State-Province Joint Engineering Laboratory of Marine Bioproducts and Technology, \\ College of Ocean \& Earth Sciences, Xiamen University, Xiamen 361102, China; dqfeng@xmu.edu.cn \\ * Correspondence: peiyueh@vip.163.com (Y.-H.P.); huyoucai@imm.ac.cn (Y.-C.H.); \\ Tel.: +86-024-23986485 (Y.-H.P.); +86-010-61271883 (Y.-C.H.) \\ + These authors contributed equally to this work.
}

Received: 24 October 2018; Accepted: 14 November 2018; Published: 16 November 2018

\begin{abstract}
Six new diphenyl ethers (1-6) along with eleven known analogs were isolated from the ethyl acetate extract of a marine-derived Aspergillus sydowii guided by LC-UV-MS. Their structures were unambiguously characterized by HRESIMS, NMR, as well as chemical derivatization. Compounds 1 and $\mathbf{2}$ are rare diphenyl ether glycosides containing D-ribose. The absolute configuration of the sugar moieties in compounds 1-3 was determined by a LC-MS method. All the compounds were evaluated for their cytotoxicities against eight cancer cell lines, including 4T1, U937, PC3, HL-60, HT-29, A549, NCI-H460, and K562, and compounds 1, 5, 6, and 8-11 were found to exhibit selective cytotoxicity against different cancer cell lines.
\end{abstract}

Keywords: Aspergillus sydowii; fungal natural product; diphenyl ethers; structure elucidation; cytotoxicity

\section{Introduction}

Marine microorganisms have become an important source of pharmacologically active metabolites [1-5]. In particular, marine-derived fungi have been identified as promising producers of chemically and biologically diverse natural products [6]. The genus Aspergillus, with over 200 species, has attracted considerable attention as a rich source of bioactive compounds including polyketides, peptides, terpenoids [7-9] and others. Diphenyl ethers are a group of polyketides with simple structures that are widely distributed in various species of Aspergillus [10-13] and have been reported to show significant diverse bioactivities, such as antiviral [14], antimicrobial [14,15], $\beta$-glucuronidase enzyme inhibitory [16], radical-scavenging [17], cytotoxicity [10,14,18-24], anti-A $\beta 42$ aggregation [24], regulating actin function [25] and phytocidal activities [26]. The cytotoxicity of diphenyl ethers against a variety of cancer cell lines has been widely reported. For example, diorcinol, cordyol C, and 3,7-dihydroxy-1,9-dimethyldibenzofuran showed cytotoxicity against HeLa and DU145 cell lines with $\mathrm{IC}_{50}$ values of 1.20-7.12 $\mu \mathrm{M}$ [22]. Sinopestalotiollide D showed cytotoxicity against HeLa, HCT 116 and A549 cell lines with IC $_{50}$ values of 1.19, 2.66 and $2.14 \mu \mathrm{M}$, respectively [19]. In order to further discover novel cytotoxic diphenyl ethers from natural sources, a marine-derived fungus 
Aspergillus sydowii strain FNA026 was investigated. As a result, seventeen diphenyl ethers 1-17 (Figure 1), including six new ones (1-6) were obtained from the ethyl acetate extract of $A$. sydowii guided by LC-UV-MS. Among them, compounds 1-3 were identified as diphenyl ether glycosides which are rare in marine secondary metabolites. Herein, we report the isolation, structure elucidation and cytotoxicities of the isolated compounds.<smiles>[R]c1c(Oc2cc([3H])cc(O)c2)cc([3H])cc1O[C@@H]1O[C@H](CO)[C@@H](O)[C@H]1O</smiles><smiles>[R]Oc1cc([R])c([R])c(Oc2cc(C)c([R2])c([R9])c2[R])c1[R]</smiles>

1: $\mathrm{R}=\mathrm{OH}$

2: $\mathrm{R}=\mathrm{H}$

3: $\mathrm{R}_{1}=\mathrm{Glc} ; \mathrm{R}_{2}=\mathrm{COOCH}_{3} ; \mathrm{R}_{3}=\mathrm{H} ; \mathrm{R}_{4}=\mathrm{CH}_{3} ; \mathrm{R}_{5}=\mathrm{R}_{6}=\mathrm{R}_{7}=\mathrm{H}$

4: $\mathrm{R}_{1}=\mathrm{H} ; \mathrm{R}_{2}=\mathrm{COOH} ; \mathrm{R}_{3}=\mathrm{H} ; \mathrm{R}_{4}=\mathrm{OH} ; \mathrm{R}_{5}=\mathrm{COOEt} ; \mathrm{R}_{6}=\mathrm{R}_{7}=\mathrm{H}$

5: $\mathrm{R}_{1}=\mathrm{R}_{2}=\mathrm{H} ; \mathrm{R}_{3}=\mathrm{H} ; \mathrm{R}_{4}=\mathrm{CH}_{2} \mathrm{CH}_{3} ; \mathrm{R}_{5}=\mathrm{R}_{6}=\mathrm{R}_{7}=\mathrm{H}$<smiles>Cc1cc(O)c2c(c1)Oc1c(C)cc(O)c(O)c1O2</smiles>

13<smiles>Cc1cc(O)cc2oc3cc(O)cc(C)c3c12</smiles>

15
6: $\mathrm{R}_{1}=\mathrm{H} ; \mathrm{R}_{2}=\mathrm{OH} ; \mathrm{R}_{3}=\mathrm{H} ; \mathrm{R}_{4}=\mathrm{CH}_{3} ; \mathrm{R}_{5}=\mathrm{R}_{6}=\mathrm{R}_{7}=\mathrm{H}$

6a: $\mathrm{R}_{1}=\mathrm{CH}_{3} ; \mathrm{R}_{2}=\mathrm{OCH}_{3} ; \mathrm{R}_{3}=\mathrm{H} ; \mathrm{R}_{4}=\mathrm{CH}_{3} ; \mathrm{R}_{5}=\mathrm{R}_{6}=\mathrm{H} ; \mathrm{R}_{7}=\mathrm{CH}_{3}$

7: $\mathrm{R}_{1}=\mathrm{H} ; \mathrm{R}_{2}=\mathrm{COOCH}_{3} ; \mathrm{R}_{3}=\mathrm{H} ; \mathrm{R}_{4}=\mathrm{CH}_{3} ; \mathrm{R}_{5}=\mathrm{R}_{6}=\mathrm{R}_{7}=\mathrm{H}$

8: $\mathrm{R}_{1}=\mathrm{R}_{2}=\mathrm{R}_{3}=\mathrm{H} ; \mathrm{R}_{4}=\mathrm{CH}_{3} ; \mathrm{R}_{5}=\mathrm{R}_{6}=\mathrm{R}_{7}=\mathrm{H}$

9: $\mathrm{R}_{1}=\mathrm{H} ; \mathrm{R}_{2}=\mathrm{COOH} ; \mathrm{R}_{3}=\mathrm{H} ; \mathrm{R}_{4}=\mathrm{CH}_{3} ; \mathrm{R}_{5}=\mathrm{R}_{6}=\mathrm{H} ; \mathrm{R}_{7}=\mathrm{CH}_{2} \mathrm{CHOHCH}_{2} \mathrm{OH}$

10: $\mathrm{R}_{1}=\mathrm{R}_{2}=\mathrm{R}_{3}=\mathrm{H} ; \mathrm{R}_{4}=\mathrm{CH}_{3} ; \mathrm{R}_{5}=\mathrm{H} ; \mathrm{R}_{6}=\mathrm{OH} ; \mathrm{R}_{7}=\mathrm{H}$

11: $\mathrm{R}_{1}=\mathrm{H} ; \mathrm{R}_{2}=\mathrm{COOCH}_{3} ; \mathrm{R}_{3}=\mathrm{H} ; \mathrm{R}_{4}=\mathrm{CH}_{3} ; \mathrm{R}_{5}=\mathrm{H} ; \mathrm{R}_{6}=\mathrm{OH} ; \mathrm{R}_{7}=\mathrm{H}$

12: $\mathrm{R}_{1}=\mathrm{H} ; \mathrm{R}_{2}=\mathrm{COOCH}_{3} ; \mathrm{R}_{3}=\mathrm{H} ; \mathrm{R}_{4}=\mathrm{CH}_{3} ; \mathrm{R}_{5}=\mathrm{COOH} ; \mathrm{R}_{6}=\mathrm{R}_{7}=\mathrm{H}$

14: $\mathrm{R}_{1}=\mathrm{R}_{2}=\mathrm{H} ; \mathrm{R}_{3}=\mathrm{OH} ; \mathrm{R}_{4}=\mathrm{CH}_{3} ; \mathrm{R}_{5}=\mathrm{H} ; \mathrm{R}_{6}=\mathrm{OCH}_{3} ; \mathrm{R}_{7}=\mathrm{H}$

16: $\mathrm{R}_{1}=\mathrm{H} ; \mathrm{R}_{2}=\mathrm{COOH} ; \mathrm{R}_{3}=\mathrm{H} ; \mathrm{R}_{4}=\mathrm{CH}_{3} ; \mathrm{R}_{5}=\mathrm{R}_{6}=\mathrm{R}_{7}=\mathrm{H}$

17: $\mathrm{R}_{1}=\mathrm{R}_{2}=\mathrm{H} ; \mathrm{R}_{3}=\mathrm{OH} ; \mathrm{R}_{4}=\mathrm{CH}_{3} ; \mathrm{R}_{5}=\mathrm{H} ; \mathrm{R}_{6}=\mathrm{OH} ; \mathrm{R}_{7}=\mathrm{H}$

Figure 1. Structures of compounds 1-17 and 6a.

\section{Results and Discussion}

Compound 1 was obtained as colorless oil. Its IR spectrum suggested the presence of hydroxy $\left(3320 \mathrm{~cm}^{-1}\right)$ and aromatic $\left(1596,1512\right.$, and $\left.1464 \mathrm{~cm}^{-1}\right)$ groups. The molecular formula of 1 was established as $\mathrm{C}_{19} \mathrm{H}_{22} \mathrm{O}_{8}$ on the basis of HRESIMS, which gave a sodium adduct ion at $m / z 401.1206$ $[\mathrm{M}+\mathrm{Na}]^{+}$. The ${ }^{1} \mathrm{H}$ NMR spectrum (in DMSO- $d_{6}$ ) of $\mathbf{1}$ exhibited signals for two methyl groups at $\delta_{\mathrm{H}} 2.15(3 \mathrm{H}, \mathrm{s}), 2.18(3 \mathrm{H}, \mathrm{s})$, five aromatic protons at $\delta_{\mathrm{H}} 6.02(1 \mathrm{H}, \mathrm{brs}), 6.12(1 \mathrm{H}, \mathrm{brs}), 6.21(1 \mathrm{H}, \mathrm{brs})$, $6.46(1 \mathrm{H}, \mathrm{brs})$ and $6.81(1 \mathrm{H}, \mathrm{brs})$, as well as two phenolic hydroxy groups at $\delta_{\mathrm{H}} 8.41(1 \mathrm{H}, \mathrm{s})$ and 9.26 $(1 \mathrm{H}, \mathrm{s})$. Analysis of its ${ }^{13} \mathrm{C}$ NMR and HSQC spectra (see Supplementary Information Figures S4 and S6) indicated the presence of five $\mathrm{sp}^{2}$ methines at $\delta_{\mathrm{C}} 100.3,107.5,109.6,112.9$, and 115.9, seven $\mathrm{sp}^{2}$ quaternary carbons at $\delta_{\mathrm{C}} 127.3,137.3,139.5,142.0,145.7,158.2$, and 159.1 and two methyl carbons at $\delta_{\mathrm{C}}$ 20.6 and 21.2. Careful analysis of the ${ }^{1} \mathrm{H}$ NMR and ${ }^{13} \mathrm{C}$ NMR data (Tables 1 and 2) of $\mathbf{1}$ indicated that it was a diphenyl ether derivative with one tetra-substituted phenyl and one trisubstituted phenyl groups, as well as an additional pentose residue. The aglycone of $\mathbf{1}$ was identified as cordyol C [14] by comparison of the 1D NMR data of $\mathbf{1}$ with those of cordyol $\mathrm{C}$ and was supported by the key HMBC correlations from $\mathrm{H}_{3}-7\left(\delta_{\mathrm{H}} 2.18\right)$ to $\mathrm{C}-4\left(\delta_{\mathrm{C}} 112.9\right), \mathrm{C}-5\left(\delta_{\mathrm{C}} 127.3\right)$, and C-6 $\left(\delta_{\mathrm{C}} 115.9\right)$, and from 2-OH $\left(\delta_{\mathrm{H}} 8.41\right)$ to $\mathrm{C}-1\left(\delta_{\mathrm{C}} 142.0\right), \mathrm{C}-2\left(\delta_{\mathrm{C}} 137.3\right)$ and $\mathrm{C}-3\left(\delta_{\mathrm{C}} 145.7\right)$, from $3^{\prime}-\mathrm{OH}\left(\delta_{\mathrm{H}} 9.26\right)$ to C-2' $\left(\delta_{\mathrm{C}} 100.3\right)$, $\mathrm{C}-3^{\prime}\left(\delta_{\mathrm{C}} 158.2\right)$, and $\mathrm{C}-4^{\prime}\left(\delta_{\mathrm{C}} 109.6\right)$, as well as from $\mathrm{H}_{3}-7^{\prime}\left(\delta_{\mathrm{H}} 2.15\right)$ to $\mathrm{C}-4^{\prime}\left(\delta_{\mathrm{C}} 109.6\right), \mathrm{C}-5^{\prime}\left(\delta_{\mathrm{C}} 139.5\right)$, and $C-6^{\prime}\left(\delta_{C} 107.5\right)$. The pentose residue in 1 showed signals at $\delta_{C} 101.3,72.3,69.4,86.7$ and 61.6 in its ${ }^{13} \mathrm{C}$ NMR spectrum and an anomeric proton $\delta_{\mathrm{H}} 5.50(1 \mathrm{H}, \mathrm{d}, J=4.6 \mathrm{~Hz})$ in its ${ }^{1} \mathrm{H}$ NMR spectrum, which suggested the presence of an $\alpha$-ribofuranosyl moiety [27]. The key HMBC correlation from H-1" $\left(\delta_{\mathrm{H}} 5.50\right)$ to $\mathrm{C}-3\left(\delta_{\mathrm{C}} 145.7\right)$ (Figure 2$)$ established the connection between the ribose and the diphenyl 
ether moiety. The $\alpha$-ribose was determined to have a D-configuration by comparison in LC-MS of the retention time of the thiocarbamoyl-thiazolidine derivative prepared after hydrolisis of $\mathbf{1}$ with those obtained from D-ribose and L-ribose standards (see Supplementary Information Figure S54). Thus, compound 1 was characterized as cordyol C-3-O- $\alpha$-D-ribofuranoside.

Table 1. The ${ }^{1} \mathrm{H}$ NMR spectroscopic data for compounds $\mathbf{1 - 6}$ and $\mathbf{6 a}(600 \mathrm{MHz})$.

\begin{tabular}{|c|c|c|c|c|c|c|c|}
\hline \multirow{2}{*}{ NO. } & \multicolumn{7}{|c|}{$\delta_{\mathrm{H}}(J$ in $\mathrm{Hz})$} \\
\hline & $1^{a}$ & $2^{b}$ & $3^{a}$ & $4^{b}$ & $5^{b}$ & $6^{b}$ & $6 a^{b}$ \\
\hline 2 & & $6.20 \mathrm{t}(2.2)$ & $6.57 \mathrm{t}(2.4)$ & $6.24 \mathrm{~d}(2.3)$ & 6.21 brs & $6.13 \mathrm{t}(2.4)$ & $6.30 \mathrm{~d}(2.2)$ \\
\hline 4 & $6.81 \mathrm{brs}$ & $6.27 \mathrm{brs}$ & $6.75 \mathrm{brs}$ & $6.35 \mathrm{~d}(2.3)$ & $6.30 \mathrm{~m}$ & 6.28 brs & $6.48 \mathrm{brs}$ \\
\hline 6 & 6.46 brs & $6.37 \mathrm{brs}$ & $6.53 \mathrm{brs}$ & & $6.39 \mathrm{~m}$ & $6.20 \mathrm{brs}$ & $6.43 \mathrm{brs}$ \\
\hline 7 & $2.18 \mathrm{~s}$ & $2.27 \mathrm{~s}$ & $2.26 \mathrm{~s}$ & $2.47 \mathrm{~s}$ & $2.53 \mathrm{q}(7.5)$ & $2.19 \mathrm{~s}$ & $2.26 \mathrm{~s}$ \\
\hline 8 & & & & & $1.18 \mathrm{t}(7.5)$ & & $3.73 \mathrm{~s}$ \\
\hline 9 & & & & $4.40 \mathrm{q}(7.5)$ & & & \\
\hline 10 & & & & $1.40 \mathrm{t}(7.5)$ & & & \\
\hline $2^{\prime}$ & 6.02 brs & $6.57 \mathrm{t}(2.8)$ & $6.28 \mathrm{~d}(2.3)$ & $6.28 \mathrm{~d}(2.7)$ & $6.21 \mathrm{brs}$ & $6.33 \mathrm{~d}(2.8)$ & $6.52 \mathrm{~d}(2.8)$ \\
\hline $4^{\prime}$ & $6.21 \mathrm{brs}$ & $6.45 \mathrm{brs}$ & & & $6.28 \mathrm{brs}$ & & \\
\hline $6^{\prime}$ & $6.12 \mathrm{brs}$ & $6.72 \mathrm{brs}$ & $6.37 \mathrm{~d}(2.3)$ & $6.56 \mathrm{~d}(2.7)$ & $6.36 \mathrm{brs}$ & $6.26 \mathrm{~d}(2.8)$ & $6.37 \mathrm{~d}(2.8)$ \\
\hline $7^{\prime}$ & $2.15 \mathrm{~s}$ & $2.22 \mathrm{~s}$ & $2.21 \mathrm{~s}$ & $2.35 \mathrm{~s}$ & $2.22 \mathrm{~s}$ & $2.17 \mathrm{~s}$ & $2.20 \mathrm{~s}$ \\
\hline $8^{\prime}$ & & & & & & & $3.78 \mathrm{~s}$ \\
\hline $9^{\prime}$ & & & $3.78 \mathrm{~s}$ & & & & $3.75 \mathrm{~s}$ \\
\hline $1^{\prime \prime}$ & $5.50 \mathrm{~d}(4.6)$ & $5.57 \mathrm{~d}(4.5)$ & $5.35 \mathrm{~d}(3.6)$ & & & & \\
\hline $2^{\prime \prime}$ & $\begin{array}{c}4.07 \text { ddd } \\
(10.7,6.8,4.1)\end{array}$ & $4.15 \mathrm{dd}(6.5,4.5)$ & $3.33 \mathrm{~m}$ & & & & \\
\hline $3^{\prime \prime}$ & $\begin{array}{c}3.93 \text { ddd } \\
(11.7,5.9,2.7)\end{array}$ & $4.06 \mathrm{dd}(6.5,3.2)$ & $3.58 \mathrm{t}(9.2)$ & & & & \\
\hline $4^{\prime \prime}$ & $3.98 \mathrm{q}(4.0)$ & $4.12 \mathrm{dd}(6.9,3.5)$ & $3.17 \mathrm{t}(9.2)$ & & & & \\
\hline $5^{\prime \prime}$ & 3.46 brt (5.1) & $\begin{array}{l}3.63 \mathrm{dd}(12.1,3.9) \\
3.69 \mathrm{dd}(11.7,3.4)\end{array}$ & $3.42 \mathrm{~m}$ & & & & \\
\hline $6^{\prime \prime}$ & & & $\begin{array}{l}3.47 \mathrm{dd}(11.7,5.2) \\
3.55 \mathrm{dd}(11.8,1.8)\end{array}$ & & & & \\
\hline $2^{\prime}-\mathrm{OH}$ & $8.41 \mathrm{~s}$ & & & & & & \\
\hline 3"-OH & $9.26 \mathrm{~s}$ & & $10.26 \mathrm{~s}$ & & & & \\
\hline $2^{\prime}-\mathrm{OH}$ & $5.14 \mathrm{~d}(6.0)$ & & & & & & \\
\hline 3"-OH & 5.16 brs & & & & & & \\
\hline $5^{\prime \prime}-\mathrm{OH}$ & $4.81 \mathrm{t}(5.6)$ & & & & & & \\
\hline
\end{tabular}

Compound 2 was isolated as colorless oil. Its molecular formula was determined to be $\mathrm{C}_{19} \mathrm{H}_{22} \mathrm{O}_{7}$, having one oxygen less than that of $\mathbf{1}$, on the basis of HRESIMS data. The detailed analysis of the ${ }^{1} \mathrm{H}$ NMR and ${ }^{13} \mathrm{C}$ NMR data (Tables 1 and 2) of 2 indicated that it had a diphenyl ether moiety with two trisubstituted benzene rings, and an additional pentose residue. The two trisubstituted rings were assigned by the HMBC correlations (Figure 2$)$ from $\mathrm{H}_{3}-7\left(\delta_{\mathrm{H}} 2.27\right)$ to $\mathrm{C}-4\left(\delta_{\mathrm{C}} 111.8\right), \mathrm{C}-5\left(\delta_{\mathrm{C}} 141.6\right)$, C-6 $\left(\delta_{\mathrm{C}} 112.1\right)$ and from $\mathrm{H}-2\left(\delta_{\mathrm{H}} 6.20\right)$ to $\mathrm{C}-1\left(\delta_{\mathrm{C}} 159.6\right), \mathrm{C}-4\left(\delta_{\mathrm{C}} 111.8\right), \mathrm{C}-6\left(\delta_{\mathrm{C}} 112.1\right)$; from $\mathrm{H}_{3}-7^{\prime}\left(\delta_{\mathrm{H}} 2.22\right)$ to $\mathrm{C}-4^{\prime}\left(\delta_{\mathrm{C}} 114.2\right), \mathrm{C}-5^{\prime}\left(\delta_{\mathrm{C}} 141.7\right), \mathrm{C}-6^{\prime}\left(\delta_{\mathrm{C}} 113.5\right)$ and H-2' $\left(\delta_{\mathrm{H}} 6.57\right)$ to $\mathrm{C}-1^{\prime}\left(\delta_{\mathrm{C}} 159.7\right), \mathrm{C}-4^{\prime}\left(\delta_{\mathrm{C}} 114.2\right)$, C- $6^{\prime}\left(\delta_{\mathrm{C}} 113.5\right)$. The anomeric proton signal at $\delta_{\mathrm{H}} 5.57(1 \mathrm{H}, \mathrm{d}, J=4.5 \mathrm{~Hz})$ in its ${ }^{1} \mathrm{H}$ NMR spectrum, and carbon signals at $\delta_{\mathrm{C}} 102.3,73.4,71.2,87.5$ and 63.2 in its ${ }^{13} \mathrm{C}$ NMR spectrum suggested the pentose residue in $\mathbf{2}$ was an $\alpha$-ribofuranosyl. The sugar moiety in $\mathbf{2}$ was identified as D-ribose by using the same method as described for $\mathbf{1}$ (see Supplementary Information Figure S55). The key HMBC correlation 
from $\mathrm{H}-1$ " $\left(\delta_{\mathrm{H}} 5.57\right)$ to $\mathrm{C}-3\left(\delta_{\mathrm{C}} 159.5\right)$ (Figure 2$)$ established the connection between the ribose and the diphenyl ether moiety. As a result, compound 2 was determined as diorcinol-3-O- $\alpha$-D-ribofuranoside.

Table 2. ${ }^{13} \mathrm{C}$ NMR spectroscopic data for compounds $\mathbf{1 - 6}$ and $\mathbf{6 a}(150 \mathrm{MHz})$.

\begin{tabular}{|c|c|c|c|c|c|c|c|}
\hline \multirow{2}{*}{ NO. } & \multicolumn{7}{|c|}{$\delta_{\mathrm{C}}$, Type } \\
\hline & $1^{a}$ & $2^{b}$ & $3^{a}$ & $4^{b}$ & $5^{b}$ & $6^{b}$ & $6 a^{b}$ \\
\hline 1 & $142.0(\mathrm{C})$ & $159.6(\mathrm{C})$ & $156.1(\mathrm{C})$ & $163.2(\mathrm{C})$ & $159.5(\mathrm{C})$ & $161.2(\mathrm{C})$ & $160.2(\mathrm{C})$ \\
\hline 2 & $137.3(\mathrm{C})$ & $106.3(\mathrm{CH})$ & $105.5(\mathrm{CH})$ & $103.9(\mathrm{C})$ & $104.5(\mathrm{CH})$ & $102.8(\mathrm{CH})$ & $102.6(\mathrm{CH})$ \\
\hline 3 & $145.7(\mathrm{C})$ & $159.5(\mathrm{C})$ & $158.3(\mathrm{C})$ & $164.9(\mathrm{C})$ & $159.7(\mathrm{C})$ & $159.4(\mathrm{C})$ & $162.3(\mathrm{C})$ \\
\hline 4 & $112.9(\mathrm{CH})$ & $111.8(\mathrm{CH})$ & $113.5(\mathrm{CH})$ & $113.3(\mathrm{CH})$ & $111.7(\mathrm{CH})$ & $111.0(\mathrm{CH})$ & $110.3(\mathrm{CH})$ \\
\hline 5 & $127.3(\mathrm{C})$ & $141.6(\mathrm{C})$ & $140.5(\mathrm{C})$ & $144.1(\mathrm{C})$ & $148.2(\mathrm{C})$ & $141.4(\mathrm{C})$ & $141.7(\mathrm{C})$ \\
\hline 6 & $115.9(\mathrm{CH})$ & $112.1(\mathrm{CH})$ & $113.6(\mathrm{CH})$ & $109.7(\mathrm{CH})$ & $110.8(\mathrm{CH})$ & $110.4(\mathrm{CH})$ & $112.2(\mathrm{CH})$ \\
\hline 7 & $20.6\left(\mathrm{CH}_{3}\right)$ & $21.6\left(\mathrm{CH}_{3}\right)$ & $21.1\left(\mathrm{CH}_{3}\right)$ & $23.9\left(\mathrm{CH}_{3}\right)$ & $29.8\left(\mathrm{CH}_{2}\right)$ & $21.6\left(\mathrm{CH}_{3}\right)$ & $21.7\left(\mathrm{CH}_{3}\right)$ \\
\hline 8 & & & & $172.4(\mathrm{C})$ & $15.9\left(\mathrm{CH}_{3}\right)$ & & $55.7\left(\mathrm{CH}_{3}\right)$ \\
\hline 9 & & & & $62.5\left(\mathrm{CH}_{2}\right)$ & & & \\
\hline 10 & & & & $14.5\left(\mathrm{CH}_{3}\right)$ & & & \\
\hline $1^{\prime}$ & $159.1(\mathrm{C})$ & $159.7(\mathrm{C})$ & $158.9(\mathrm{C})$ & $160.8(\mathrm{C})$ & $159.6(\mathrm{C})$ & $150.1(\mathrm{C})$ & $154.3(\mathrm{C})$ \\
\hline $2^{\prime}$ & $100.3(\mathrm{CH})$ & $104.3(\mathrm{CH})$ & $102.6(\mathrm{CH})$ & $106.4(\mathrm{CH})$ & $104.2(\mathrm{CH})$ & $106.1(\mathrm{CH})$ & $103.4(\mathrm{CH})$ \\
\hline $3^{\prime}$ & $158.2(\mathrm{C})$ & $159.4(\mathrm{C})$ & $157.6(\mathrm{C})$ & $155.0(\mathrm{C})$ & $159.7(\mathrm{C})$ & $146.8(\mathrm{C})$ & $154.8(\mathrm{C})$ \\
\hline $4^{\prime}$ & $109.6(\mathrm{CH})$ & $114.2(\mathrm{CH})$ & $114.9(\mathrm{C})$ & $120.1(\mathrm{C})$ & $111.9(\mathrm{CH})$ & $140.8(\mathrm{C})$ & $144.5(\mathrm{C})$ \\
\hline $5^{\prime}$ & $139.5(\mathrm{C})$ & $141.7(\mathrm{C})$ & $139.1(\mathrm{C})$ & $140.6(\mathrm{C})$ & $141.6(\mathrm{C})$ & $126.7(\mathrm{C})$ & $133.5(\mathrm{C})$ \\
\hline $6^{\prime}$ & $107.5(\mathrm{CH})$ & $113.5(\mathrm{CH})$ & $110.7(\mathrm{CH})$ & $114.9(\mathrm{CH})$ & $110.6(\mathrm{CH})$ & $113.6(\mathrm{CH})$ & $113.7(\mathrm{CH})$ \\
\hline $7^{\prime}$ & $21.2\left(\mathrm{CH}_{3}\right)$ & $21.5\left(\mathrm{CH}_{3}\right)$ & $20.1\left(\mathrm{CH}_{3}\right)$ & $20.2\left(\mathrm{CH}_{3}\right)$ & $21.5\left(\mathrm{CH}_{3}\right)$ & $16.2\left(\mathrm{CH}_{3}\right)$ & $16.0\left(\mathrm{CH}_{3}\right)$ \\
\hline $8^{\prime}$ & & & $168.5(\mathrm{C})$ & $170.7(\mathrm{C})$ & & & $56.3\left(\mathrm{CH}_{3}\right)$ \\
\hline $9^{\prime}$ & & & $51.9\left(\mathrm{CH}_{3}\right)$ & & & & $60.6\left(\mathrm{CH}_{3}\right)$ \\
\hline $1^{\prime \prime}$ & $101.3(\mathrm{CH})$ & $102.3(\mathrm{CH})$ & $97.9(\mathrm{CH})$ & & & & \\
\hline $2^{\prime \prime}$ & $72.3(\mathrm{CH})$ & $73.4(\mathrm{CH})$ & $71.5(\mathrm{CH})$ & & & & \\
\hline $3^{\prime \prime}$ & $69.4(\mathrm{CH})$ & $71.2(\mathrm{CH})$ & $73.0(\mathrm{CH})$ & & & & \\
\hline $4^{\prime \prime}$ & $86.7(\mathrm{CH})$ & $87.5(\mathrm{CH})$ & $69.8(\mathrm{CH})$ & & & & \\
\hline $5^{\prime \prime}$ & $61.6\left(\mathrm{CH}_{2}\right)$ & $63.2\left(\mathrm{CH}_{2}\right)$ & $73.8(\mathrm{CH})$ & & & & \\
\hline $6^{\prime \prime}$ & & & $60.6\left(\mathrm{CH}_{2}\right)$ & & & & \\
\hline
\end{tabular}

${ }^{\text {a }}$ Recorded in DMSO- $d_{6} ;{ }^{\mathrm{b}}$ Recorded in $\mathrm{CD}_{3} \mathrm{OD}$

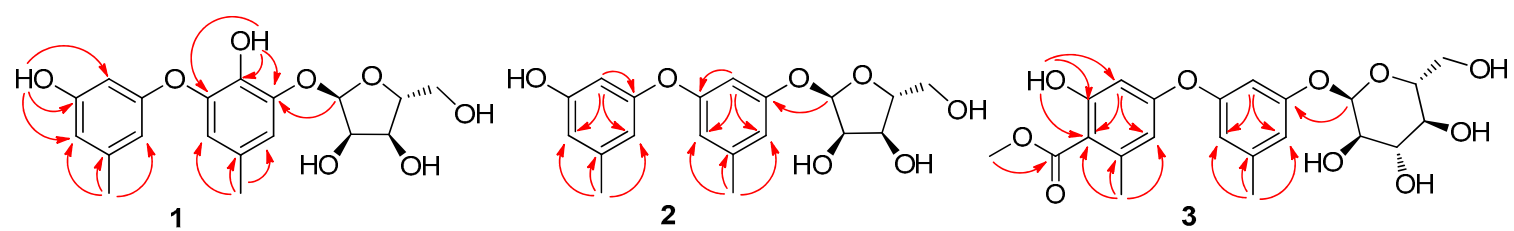<smiles>CCOC(=O)c1c(C)cc(O)cc1Oc1cc(C)c(C(=O)O)c(O)c1</smiles><smiles>CC1C2CC3CC(C2)CC1(Oc1ccc(O)c(OC24CC5CC(CC(C5)C2)C4)c1)C3</smiles><smiles>COc1cc(C)cc(Oc2cc(C)c(OC)c(OC)c2)c1</smiles>

$6 a$

Figure 2. Key ${ }^{1} \mathrm{H}^{-1} \mathrm{H}$ COSY (blue lines) and key HMBC (arrows) correlations of $\mathbf{1 - 5}$ and $\mathbf{6 a}$.

The molecular formula $\mathrm{C}_{22} \mathrm{H}_{26} \mathrm{O}_{10}$ of compound 3 was deduced from positive HRESIMS which gave a sodium adduct ion at $m / z 473.1403[\mathrm{M}+\mathrm{Na}]^{+}$. Its ${ }^{13} \mathrm{C}$ NMR spectrum (Table 2) displayed 22 carbon resonances, including 6 signals for a hexose residue at $\delta_{\mathrm{C}} 97.9,71.5,73.0,69.8,73.8$ and 60.6, suggesting 3 to be a glucoside [28]. The ${ }^{1} \mathrm{H}$ and ${ }^{13} \mathrm{C}$ NMR spectra for 3 (Tables 1 and 2) indicated the aglycone in 3 as 4-methoxycarbonyl diorcinol [8], which was supported by key HMBC correlations from $\mathrm{H}_{3}-7\left(\delta_{\mathrm{H}} 2.26\right)$ to $\mathrm{C}-4\left(\delta_{\mathrm{C}} 113.5\right), \mathrm{C}-5\left(\delta_{\mathrm{C}} 140.5\right), \mathrm{C}-6\left(\delta_{\mathrm{C}} 113.6\right)$ and from H-2 $\left(\delta_{\mathrm{H}} 6.57\right)$ to $\mathrm{C}-4$ $\left(\delta_{\mathrm{C}} 113.5\right), \mathrm{C}-6\left(\delta_{\mathrm{C}} 113.6\right)$, from $\mathrm{H}_{3}-7^{\prime}\left(\delta_{\mathrm{H}} 2.21\right)$ to $\mathrm{C}-4^{\prime}\left(\delta_{\mathrm{C}} 114.9\right), \mathrm{C}-5^{\prime}\left(\delta_{\mathrm{C}} 139.1\right), \mathrm{C}-6^{\prime}\left(\delta_{\mathrm{C}} 110.7\right)$, from $\mathrm{H}-2^{\prime}\left(\delta_{\mathrm{H}} 6.28\right)$ to $\mathrm{C}-4^{\prime}\left(\delta_{\mathrm{C}} 114.9\right), \mathrm{C}-6^{\prime}\left(\delta_{\mathrm{C}} 110.7\right)$, and from $3^{\prime}-\mathrm{OH}\left(\delta_{\mathrm{H}} 10.26\right)$ to C-2' $\left(\delta_{\mathrm{C}} 102.6\right)$, $\mathrm{C}-3^{\prime}\left(\delta_{\mathrm{C}} 157.6\right), \mathrm{C}-4^{\prime}\left(\delta_{\mathrm{C}} 114.9\right)$, as well as from $\mathrm{H}_{3}-9^{\prime}\left(\delta_{\mathrm{H}} 3.78\right)$ to $\mathrm{C}-8^{\prime}\left(\delta_{\mathrm{C}} 168.5\right)$. The anomeric signal at 
$\delta_{\mathrm{H}} 5.35(1 \mathrm{H}, \mathrm{d}, J=3.6 \mathrm{~Hz}) / \delta_{\mathrm{C}} 97.9\left(\mathrm{C}-1^{\prime \prime}\right)$ and the one-bond coupling constant of $172.9 \mathrm{~Hz}$ between C-1" and H-1" (see Supplementary Information Figure S23) supported an $\alpha$-configuration of the $\mathrm{O}$-glucoside [29]. The absolute configuration of glucose moiety in 3 was determined as D-glucose based on LC-ESI-MS analysis (see Supplementary Information Figure S56). The key HMBC correlation from $\mathrm{H}-1 " \prime\left(\delta_{\mathrm{H}} 5.35\right)$ to $\mathrm{C}-3\left(\delta_{\mathrm{C}} 158.3\right)$ (Figure 2$)$ established the connection between the glucose and diphenyl ether moiety. Thus, the structure of compound 3 was determined to be 4-methoxycarbonyl diorcinol-3-O- $\alpha$-D-glucoside.

Compound 4 was obtained as colorless oil. Its molecular formula was determined to be $\mathrm{C}_{18} \mathrm{H}_{18} \mathrm{O}_{7}$ by HRESIMS, having a fragment of $\mathrm{C}_{3} \mathrm{H}_{4} \mathrm{O}_{2}$ more than that of 4-carboxydiorcinal (16). The ${ }^{1} \mathrm{H}$ and ${ }^{13} \mathrm{C}$ NMR spectra for $\mathbf{4}$ (Tables 1 and 2) and $\mathbf{1 6}$ showed very similar signals, with the exception that H-6 at $\delta_{\mathrm{H}} 6.17$ for 16 was missing for 4 , which indicated that the $\mathrm{CH}$ at $\mathrm{C}-6$ in 16 was replaced by another substitution in 4. Analysis of the ${ }^{1} \mathrm{H}$ NMR and ${ }^{13} \mathrm{C}$ NMR (Tables 1 and 2) and ${ }^{1} \mathrm{H}-{ }^{1} \mathrm{H}$ COSY correlation data (Figure 2) of 4 indicated the presence of an ester carbonyl (C-8) at $\delta_{\mathrm{C}} 172.4$ and an oxygenated ethyl group (C-9/C-10) at $\delta_{\mathrm{C}} 62.5$ and $\delta_{\mathrm{C}} 14.5$. The presence of an ethyl ester unit was confirmed by the HMBC correlation from $\mathrm{H}_{2}-9\left(\delta_{\mathrm{H}} 4.40\right)$ to $\mathrm{C}-8\left(\delta_{\mathrm{C}} 172.4\right)$ (Figure 2$)$. Thus, the structure of 4 was elucidated as 2-(ethoxycarbonyl)- $4^{\prime}$-carboxydiorcinal.

The HRESIMS of 5 displayed a protonated ion $[\mathrm{M}+\mathrm{H}]^{+}$at $m / z 245.1183$, corresponding to the molecular formula of $\mathrm{C}_{15} \mathrm{H}_{16} \mathrm{O}_{3}$, one more carbon and two more hydrogens than that of diorcinol (8). The ${ }^{1} \mathrm{H}$ and ${ }^{13} \mathrm{C}$ NMR spectra for 5 (Tables 1 and 2) and 8 showed very similar signals, with the exception that a methyl at $C-7\left(\delta_{\mathrm{C}} 21.5\right)$ in 8 was substituted by an ethyl group in 5 , which was confirmed by $\mathrm{HMBC}$ correlations from the ethyl protons at $\mathrm{H}_{2}-7\left(\delta_{\mathrm{H}} 2.53\right)$ to $\mathrm{C}-4\left(\delta_{\mathrm{C}} 111.7\right), \mathrm{C}-5\left(\delta_{\mathrm{C}} 148.2\right)$, and C-6 $\left(\delta_{\mathrm{C}}\right.$ 110.8). The full structure of 5 was further confirmed by COSY and HMBC experiments (Figure 2). As a result, 5 was elucidated as 7-ethyldiorcinol.

The molecular formula $\mathrm{C}_{14} \mathrm{H}_{14} \mathrm{O}_{4}$ of 6 was determined by negative HRESIMS at $m / z 245.0808$ $[\mathrm{M}-\mathrm{H}]^{-}$, one more oxygen than those of 8 . The ${ }^{1} \mathrm{H}$ and ${ }^{13} \mathrm{C}$ NMR spectra for 6 (Tables 1 and 2) showed very similar signals to those of 8 , with the exception that the tertiary carbon signal at $\delta_{\mathrm{C}}$ 111.8 for 8 was replaced by a quaternary carbon signal at $\delta_{C} 140.8$ for 6 . These data indicated that the hydrogen at $C-6\left(\delta_{C} 111.8\right)$ in 8 was substituted by a hydroxy group in 6 . The two hydroxy groups in the $\mathrm{B}$ ring did not display any correlation in the HMBC spectrum, and therefore the position of the ether linkage between the two benzene rings could not be determined by 2D NMR data at this stage. Therefore, full methylation of $\mathbf{6}$ was completed with $\mathrm{CH}_{3} \mathrm{I} / \mathrm{K}_{2} \mathrm{CO}_{3}$, which afforded its derivative $\mathbf{6 a}$. $\mathrm{HMBC}$ correlations of 6 a from $\mathrm{H}_{3}-8\left(\delta_{\mathrm{H}} 3.73\right)$ to $\mathrm{C}-3\left(\delta_{\mathrm{C}} 162.3\right)$, from $\mathrm{H}_{3}-8^{\prime}\left(\delta_{\mathrm{H}} 3.78\right)$ to $\mathrm{C}-3^{\prime}\left(\delta_{\mathrm{C}} 154.8\right)$ and from $\mathrm{H}_{3}-9^{\prime}\left(\delta_{\mathrm{H}} 3.75\right)$ to $\mathrm{C}-4^{\prime}\left(\delta_{\mathrm{C}} 144.5\right)$ (Figure 2$)$ demonstrated that the three free hydroxy groups of 6 were attached to C-3, C-3' and C- $4^{\prime}$, respectively. Therefore, 6 was unambiguously determined as 3-hydroxydiorcinol.

The eleven known compounds (7-17) were identified as 4-methoxycarbonyl diorcinol (7) [10], diorcinol (8) [11], glyceryl diorcinolic acid (9) [12], cordyol C (10) [14], aspergilol E (11) [13], 4-hydroxy-2-(3'-hydroxy-4-methoxycarbonyl-5'-methylphenoxy)-6-methylbenzoic acid (12) [16], gibellulin B (13) [11], diorcinols F (14) [30], 3,7-dihydroxy-1,9-dimethyldibenzofuran (15) [31], 4-carboxydiorcinal (16) [32] and aspermutarubrol (17) [33] by comparison of their spectroscopic data to those reported in the literature.

The cytotoxicity of all the isolated compounds was tested against a series of cancer cell lines, including 4T1 (Mouse Breast Cancer cell line), U937 (Human Histiocytic Lymphoma cell line), PC3 (Human Prostate Cancer cell line), HL-60 (Human Leukemia cell line), HT-29 (Human Colorectal Adenocarcinoma cell line), A549 (Human Lung Adenocarcinomic cell line), NCI-H460 (Human Large Cell Lung Cancer cell line) and K562 (Human Myelogenous Leukemia cell line), with doxorubicin (DOX) as positive control (Table 3). None of the compounds showed cytotoxicity against the five solid cancer cell lines (4T1, PC3, HT-29 and NCI-H460). Compounds 1, 5, 8 and 9 showed moderate cytotoxicity against A549. These results suggested that glycosylation of the 3-hydroxy group seems to negatively contribute to its cytotoxicity against A549 cell line (2 vs. 8), while substitution at the same 
3-OH position by a glycerol group positively compensate for cytotoxicity (16 vs. 9). In addition, compounds 1, 6, 9-11 showed selective cytotoxicity against different nonsolid cancer cell lines (U937, HL-60, and K562). Interestingly, only compounds 6, 10 and 11, which possess two adjacent hydroxy groups in one of the benzene rings and no substitution at C-2 position in the other ring exhibited varied inhibitory cytotoxicity on K562 cells. Moreover, by comparison of the structures of 9 and 3-4, 7, 11-12 and 16 having a carboxyl group, it was found that when the carboxyl group in the benzene ring is adjacent to a free hydroxy group, the cytotoxicity against HL-60 cells is lost. In summary, we found that when the ortho position of the carboxyl group in the diphenyl ethers is a free phenolic hydroxy group, it will lose all cytotoxicity against cancer cells, and the adjacent phenolic hydroxy groups confer selective cytotoxicity against several cell lines.

Table 3. Cytotoxicity $\left(\mathrm{IC}_{50}\right.$ in $\left.\mu \mathrm{M}\right)$ for compounds 1, 5-6, 8-11.

\begin{tabular}{ccccc}
\hline Compounds & A549 & U937 & HL-60 & K562 \\
\hline $\mathbf{1}$ & $8.97 \pm 0.48$ & $4.64 \pm 0.35$ & $/$ & $/$ \\
$\mathbf{5}$ & $16.13 \pm 1.24$ & $/$ & $/$ & $/$ \\
$\mathbf{6}$ & $/$ & $/$ & $11.98 \pm 0.73$ & $18.89 \pm 1.14$ \\
$\mathbf{8}$ & $15.51 \pm 1.59$ & $/$ & $/$ & $/$ \\
$\mathbf{9}$ & $3.36 \pm 0.68$ & $/$ & $21.22 \pm 1.25$ & $/$ \\
$\mathbf{1 0}$ & $/$ & $/$ & $16.52 \pm 0.99$ & $20.88 \pm 1.60$ \\
$\mathbf{1 1}$ & $/$ & $13.33 \pm 0.87$ & $23.03 \pm 1.34$ \\
$\mathbf{D O X}$ & $0.19 \pm 0.04$ & $<0.125$ & $<0.125$ & $0.49 \pm 0.08$ \\
\hline \multicolumn{7}{l}{ "/" no cytotoxicity was detected. Inactive compounds were not shown here. }
\end{tabular}

\section{Materials and Methods}

\subsection{General Experimental Procedures}

Optical rotations were measured with a JASCO P-2000 automatic digital polarimeter (JASCO, Easton, MD, USA). IR spectra were taken on a Nicolet 5700 FT-IR spectrometer (Termo Electron Corporation, Madison, WI, USA). The NMR spectra in $\mathrm{CD}_{3} \mathrm{OD}$ and DMSO- $d_{6}$ with TMS as internal reference were obtained on a Bruker AVANCE III HD $600 \mathrm{MHz}$ spectrometer equipped with a $5 \mathrm{~mm}$ cryogenic $\mathrm{CPDCH}$ probe (Bruker, Fällanden, Switzerland). HRESIMS were recorded on an Agilent Technologies 6520 Accurate Mass Q-TOF LC/MS spectrometer (Agilent Technologies, Santa Clara, CA, USA). Column chromatography (CC) was carried out on Sephadex LH-20 (GE Healthcare, Sweden), silica gel (300-400 mesh, Qingdao Marine Chemical Inc., Qingdao, China) and MCI gel CHP 20P/P120 (Middle Chromatogram Isolated Gel, Mitsubishi Chemical Corporation, Tokyo, Japan). LC-ESI-MS analyses were performed on a Bruker micrOTOF-Q II (Bruker, Billerica, MA, USA) using a COSMOSIL $\mathrm{C}_{18}$ column $(5 \mu \mathrm{m}, 4.6 \times 250 \mathrm{~mm})$. TLC was performed on GF254 plates (Qingdao Marine Chemical Factory, Qingdao, China). Medium pressure liquid chromatography (MPLC) was carried out on a TELEDYNE ISCO CombiFlash Rf+ [Universal Technology, Hong Kong, China]. HPLC was conducted using a SSI instrument with a Series 1500 photo diode array detector and COSMOSIL $\mathrm{C}_{18}$ column $(5 \mu \mathrm{m}, 4.6 \times 250 \mathrm{~mm})$. Standards of D/L-ribose and D/L-glucose were purchased from Sigma (St. Louis, MO, USA), and Derivatization reagents L-cysteine and o-tolyl isothiocyanate were purchased from J\&K Scientific Ltd. (Beijing, China).

\subsection{Fungal Material}

The fungal strain FNA026 was isolated from marine water collected in the sea of China, Xiamen. The voucher specimen is deposited in our laboratory at $-80^{\circ} \mathrm{C}$. The partial $18 \mathrm{~S}$ rRNA sequence was compared to sequences in available databases using the Basic Local Alignment Search Tool and strain FNA026 determined to be an Aspergillus sydowii (Supplementary Information Figure S57). 


\subsection{Fermentation}

The fungal strain FNA026 was grown on potato dextrose agar at $28^{\circ} \mathrm{C}$ for 5 days. Five pieces $\left(0.5 \times 0.5 \mathrm{~cm}^{2}\right)$ of mycelial agar plugs were inoculated into $500 \mathrm{~mL}$ Erlenmeyer flasks containing $300 \mathrm{~mL}$ of potato dextrose broth, which were then incubated on a rotary shaker at $250 \mathrm{rpm}$ and $28^{\circ} \mathrm{C}$ for 3 days. Then the seed liquid was spread in $500 \mathrm{~mL}$ Roux flasks ( 30 flasks) containing rice ( $100 \mathrm{~g}$ per flask) and artificial seawater ( $120 \mathrm{~mL}$ per flask). The flasks were incubated at $28^{\circ} \mathrm{C}$ for 4 weeks.

\subsection{Extraction and Isolation}

The extraction and isolation procedures were guided by LC-MS screening with UV absorption characteristics (207 nm and $270 \mathrm{~nm}$ ) and molecular weight $(\mathrm{m} / z$ 230-280 and $\mathrm{m} / z$ 380-480) as search criteria. The fermented rice inoculated with FNA026 $(3 \mathrm{~kg})$ was extracted three times with ethyl acetate $(500 \mathrm{~mL})$ at room temperature under sonication to give a crude extract $(28.86 \mathrm{~g})$, which was then dissolved in $\mathrm{MeOH}$, and extracted three times using petroleum ether to afford $\mathrm{MeOH}$-soluble (22.24 g) and petroleum ether-soluble $(5.65 \mathrm{~g})$ fractions. The $\mathrm{MeOH}$-soluble fraction was subjected to MCI gel (Middle Chromatogram Isolated Gel) with a stepped gradient of $\mathrm{MeOH}-\mathrm{H}_{2} \mathrm{O}(20: 80,50: 50,90: 10$, $100: 0 \mathrm{v} / \mathrm{v})$ to give 4 fractions (A-D). Fraction C ( $2.79 \mathrm{~g})$ was separated on a silica gel column eluting with a dichloromethane-methanol gradient $(1: 0-0: 1, v / v)$ to give 12 fractions $(\mathrm{C} 1-\mathrm{C} 12)$. Fraction $\mathrm{C} 4$ $(0.83 \mathrm{~g})$ was subjected to MPLC eluting with a gradient of increasing $\mathrm{MeCN}(20-50 \%)$ in $\mathrm{H}_{2} \mathrm{O}$ to give 8 fractions $(\mathrm{C} 4 \mathrm{~A}-\mathrm{C} 4 \mathrm{H})$, where pure compound $8(328.6 \mathrm{mg})$ was obtained from fraction C4D. Fraction C4A $(15.6 \mathrm{mg})$ was further purified by HPLC $\left(1.0 \mathrm{~mL} / \mathrm{min} ; 46 \% \mathrm{MeCN}\right.$ in $\left.\mathrm{H}_{2} \mathrm{O}\right)$ to give compound 9 $\left(t_{\mathrm{R}} 15.6 \mathrm{~min}, 3.5 \mathrm{mg}\right)$. Fraction C4E $(5.3 \mathrm{mg})$ was further purified by HPLC $(1.0 \mathrm{~mL} / \mathrm{min} ; 64 \% \mathrm{MeOH}$ in $\left.\mathrm{H}_{2} \mathrm{O}\right)$ to give compound $5\left(t_{\mathrm{R}} 13.2 \mathrm{~min}, 1.2 \mathrm{mg}\right)$. Fraction $\mathrm{C} 4 \mathrm{H}(22.8 \mathrm{mg})$ was further purified by HPLC $\left(1.0 \mathrm{~mL} / \mathrm{min} ; 69 \% \mathrm{MeOH}\right.$ in $\left.\mathrm{H}_{2} \mathrm{O}\right)$ to give compound $13\left(t_{\mathrm{R}} 22.2 \mathrm{~min}, 3.3 \mathrm{mg}\right)$. Fraction $\mathrm{C} 5$ (390.4 mg) was subjected to MPLC eluting with a gradient of $\mathrm{MeCN}(30-60 \%)$ in $\mathrm{H}_{2} \mathrm{O}$ to yield into 6 fractions (C5A-C5F). Fraction C5A (38.3 mg) was further purified by HPLC $(1.0 \mathrm{~mL} / \mathrm{min} ; 59 \% \mathrm{MeOH}$ in $\left.\mathrm{H}_{2} \mathrm{O}\right)$ to give compound $10\left(t_{\mathrm{R}} 17.3 \mathrm{~min}, 5.2 \mathrm{mg}\right)$. Fraction $\mathrm{C} 6(58.8 \mathrm{mg})$ was chromatographed over SephadexLH-20 and eluted with $\mathrm{MeOH}$ to yield fractions C6A-C6G. Pure compound $11(3.7 \mathrm{mg})$ was obtained directly from fraction C6C. Fraction C7 $(88.3 \mathrm{mg})$ was subjected to HPLC $(1.0 \mathrm{~mL} / \mathrm{min}$; $32 \% \mathrm{MeCN}$ in $\mathrm{H}_{2} \mathrm{O}, 0.1 \% \mathrm{TFA}$ ) to yield into 4 fractions (C7A-C7D). Pure compound 14 (3.8 mg) was obtained directly from fraction C7B. Fraction C7D $(10.9 \mathrm{mg})$ was further purified by HPLC $(1.0 \mathrm{~mL} / \mathrm{min}$; $68 \% \mathrm{MeOH}$ in $\mathrm{H}_{2} \mathrm{O}$ ) to give compound $17\left(t_{\mathrm{R}} 26.3 \mathrm{~min}, 3.1 \mathrm{mg}\right)$. Fraction $\mathrm{C} 9(22.1 \mathrm{mg})$ was purified by HPLC ( $1.0 \mathrm{~mL} / \mathrm{min} ; 43 \% \mathrm{MeCN}$ in $\left.\mathrm{H}_{2} \mathrm{O}, 0.1 \% \mathrm{TFA}\right)$ to give compound 15 ( $\left.t_{\mathrm{R}} 12.1 \mathrm{~min}, 2.2 \mathrm{mg}\right)$. Fraction $\mathrm{C} 10(476.4 \mathrm{mg})$ was subjected to MPLC eluting with a gradient of acetonitrile (30-53\%) in $\mathrm{H}_{2} \mathrm{O}$ to give 7 fractions (C10A-C10G), and two pure compounds $2(5.2 \mathrm{mg})$ and $\mathbf{1 6}(4.2 \mathrm{mg})$ were obtained directly from fraction C10C and fraction C10E, respectively. Fraction C10F (165.4 mg) was applied to a Sephadex LH-20 column chromatography eluted with $\mathrm{MeOH}$ to give 17 fractions (C10F1-C10F17). Fraction C10F7 (8.2 mg) was further purified by HPLC ( $1.0 \mathrm{~mL} / \mathrm{min} ; 42 \% \mathrm{MeCN}$ in $\left.\mathrm{H}_{2} \mathrm{O}, 0.1 \% \mathrm{TFA}\right)$ to give compound $4\left(t_{\mathrm{R}} 14.2 \mathrm{~min}, 1.7 \mathrm{mg}\right)$. Fraction C10F10 $(25.8 \mathrm{mg})$ was further purified by HPLC $\left(1.0 \mathrm{~mL} / \mathrm{min} ; 44 \% \mathrm{MeCN}\right.$ in $\left.\mathrm{H}_{2} \mathrm{O}\right)$ to give compound $6\left(t_{\mathrm{R}} 13.4 \mathrm{~min}, 1.6 \mathrm{mg}\right)$. Fraction C11 $(42.5 \mathrm{mg})$

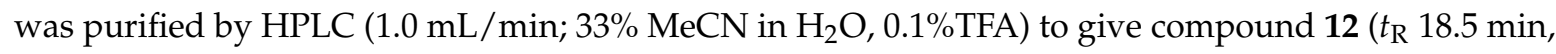
$6.4 \mathrm{mg}$ ). Fraction C12 (495.6 mg) was subjected to the Sephadex LH-20 column chromatography eluted with $\mathrm{MeOH}$ to give 8 fractions $(\mathrm{C} 12 \mathrm{~A}-\mathrm{C} 12 \mathrm{H})$. Fraction $\mathrm{C} 12 \mathrm{G}(28.6 \mathrm{mg})$ was purified by HPLC ( $1.0 \mathrm{~mL} / \mathrm{min} ; 34 \% \mathrm{MeCN}$ in $\left.\mathrm{H}_{2} \mathrm{O}, 0.1 \% \mathrm{TFA}\right)$ to give compound $1\left(t_{\mathrm{R}} 24 \mathrm{~min}, 1.3 \mathrm{mg}\right.$ ). Fraction $\mathrm{C} 12 \mathrm{H}$ (18.6 mg) was further purified by HPLC $\left(1.0 \mathrm{~mL} / \mathrm{min} ; 36 \% \mathrm{MeCN}\right.$ in $\left.\mathrm{H}_{2} \mathrm{O}, 0.1 \% \mathrm{TFA}\right)$ to give compound $3\left(t_{\mathrm{R}} 20 \mathrm{~min}, 2.2 \mathrm{mg}\right)$. Fraction $\mathrm{D}(1.33 \mathrm{~g})$ was subjected to column chromatography on silica gel and eluted with dichloromethane-methanol gradient (1:0-0:1, $v / v)$, which gave 8 fractions (D1-D8). Fraction D5 (325.2 mg) was further by MPLC eluting with a gradient of increasing MeCN (50-100\%) in $\mathrm{H}_{2} \mathrm{O}$ to give 5 fractions (D5A-D5E), and pure compound 7 (185.6 mg) was obtained directly from fraction D5C. 


\subsubsection{Cordyol C-3-O- $\alpha$-D-ribofuranoside (1)}

Colorless oil; $[\alpha]_{\mathrm{D}}^{25}-8.0$ (c 0.20, MeOH), UV(MeOH) $\lambda_{\max }(\log \varepsilon): 204.8(4.02) \mathrm{nm}, 279.4$ (3.25) nm; IR $v_{\max }: 3320.1,1677.7,1596.2,1512.1,1464.3,1322.1,1210.8,1140.0,1046.8,997.6,836.2 \mathrm{~cm}^{-1} ;{ }^{1} \mathrm{H}$ and ${ }^{13} \mathrm{C}$ NMR spectroscopic data see Tables 1 and 2; HRESIMS $m / z$ 401.1206 $\left[\mathrm{M}+\mathrm{Na}^{+}\right.$(calcd. for $^{-1}$ $\mathrm{C}_{19} \mathrm{H}_{22} \mathrm{O}_{8} \mathrm{Na}$, 401.1207).

\subsubsection{Diorcinol-3-O- $\alpha$-D-ribofuranoside (2)}

Colorless oil; $[\alpha]_{\mathrm{D}}^{25}-18.6$ (c 0.40, MeOH), UV(MeOH) $\lambda_{\max }(\log \varepsilon): 207.2(4.05) \mathrm{nm}, 273.4$ (3.25) nm; IR $v_{\max }: 3344.2,2931.4,1600.7,1464.7,1325.1,1154.9,1039.8,839.2 \mathrm{~cm}^{-1} ;{ }^{1} \mathrm{H}$ and ${ }^{13} \mathrm{C}$ NMR spectroscopic data see Tables 1 and 2; HRESIMS $m / z 385.1261[\mathrm{M}+\mathrm{Na}]^{+}$(calcd. for $\mathrm{C}_{19} \mathrm{H}_{22} \mathrm{O}_{7} \mathrm{Na}, 385.1258$ ).

\subsubsection{4-Methoxycarbonyl Diorcinol-3-O- $\alpha$-D-glucoside (3)}

Colorless oil; $[\alpha]_{\mathrm{D}}^{25}+9.6\left(c\right.$ 0.20, MeOH), UV(MeOH) $\lambda_{\max }(\log \varepsilon): 214.2(4.03) \mathrm{nm}, 261.5(3.64) \mathrm{nm}$, 298.4 (3.28) nm; IR $v_{\max }$ : 3334.5, 1651.3, 1579.3, 1454.2, 1324.9, 1268.4, 1161.2, 1023.9, $847.5 \mathrm{~cm}^{-1}$; ${ }^{1} \mathrm{H}$ and ${ }^{13} \mathrm{C}$ NMR spectroscopic data see Tables 1 and 2; HRESIMS $m / z 473.1403$ [M + Na] ${ }^{+}$(calcd. for $\mathrm{C}_{22} \mathrm{H}_{26} \mathrm{O}_{10} \mathrm{Na}$, 473.1418).

\subsubsection{2-(Ethoxycarbonyl)-4'-carboxydiorcinal (4)}

Colorless oil; UV(MeOH) $\lambda_{\max }(\log \varepsilon): 216.6(4.04) \mathrm{nm}, 259.2$ (3.59) nm, 299.6 (3.26) nm; IR $v_{\max }$ : 3251.1, 1654.4, 1613.0, 1460.1, 1317.8, 1260.4, 1167.0, 845.9, 802.3 $\mathrm{cm}^{-1} ;{ }^{1} \mathrm{H}$ and ${ }^{13} \mathrm{C}$ NMR spectroscopic data see Tables 1 and 2; HRESIMS $m / z 369.0954[\mathrm{M}+\mathrm{Na}]^{+}$(calcd. for $\left.\mathrm{C}_{18} \mathrm{H}_{18} \mathrm{O}_{7} \mathrm{Na}, 369.0945\right)$.

\subsubsection{7-Ethyldiorcinol (5)}

Colorless oil; UV(MeOH) $\lambda_{\max }(\log \varepsilon): 207.2(4.03) \mathrm{nm}, 280.5$ (3.27) nm; IR $v_{\max }$ : 3343.5, 1598.3, 1459.8, 1329.8, 1155.3, 995.4, $841.3 \mathrm{~cm}^{-1} ;{ }^{1} \mathrm{H}$ and ${ }^{13} \mathrm{C}$ NMR spectroscopic data see Tables 1 and 2; HRESIMS $m / z 245.1183[\mathrm{M}+\mathrm{H}]^{+}$(calcd. for $\mathrm{C}_{15} \mathrm{H}_{17} \mathrm{O}_{3}, 245.1172$ ).

\subsubsection{3-Hydroxydiorcinol (6)}

Colorless oil; UV(MeOH) $\lambda_{\max }(\log \varepsilon): 221.3(4.03) \mathrm{nm}, 280.5$ (3.71) nm; IR $v_{\max }$ : 3286.7, 1598.2, 1491.4, 1324.2, 1154.0, 1024.7, 976.7, $836.8 \mathrm{~cm}^{-1} ;{ }^{1} \mathrm{H}$ and ${ }^{13} \mathrm{C}$ NMR spectroscopic data see Tables 1 and 2; HRESIMS $m / z 245.0808[\mathrm{M}-\mathrm{H}]^{-}$(calcd. for $\mathrm{C}_{14} \mathrm{H}_{13} \mathrm{O}_{4}, 245.0819$ ).

\subsection{Determination of the Absolute Configuration of Sugar Moieties in 1-3}

To determine the absolute configurations of sugar moieties in 1-3, a modified method based on LC-ESI-MS analysis was performed, where the retention time of sugar samples obtained after hydrolysis of the parent compounds were compared with those from standard sugars (D/L) [34]. In detail, compounds 1, 2 and 3 (approximately $0.05 \mathrm{mg}$, each) were hydrolyzed with $2 \mathrm{~mol} / \mathrm{L} \mathrm{HCl}$ $(400 \mu \mathrm{L})$ in a $2 \mathrm{~mL}$ glass vial at $80{ }^{\circ} \mathrm{C}$ for $4 \mathrm{~h}$. The reaction mixture was then diluted with $\mathrm{H}_{2} \mathrm{O}(400 \mu \mathrm{L})$ and extracted with $\mathrm{CHCl}_{3}(400 \mu \mathrm{L})$ three times. The aqueous layer containing monosaccharides was concentrated in vacuo to yield a dried sugar mixture. The resulting sugar mixture (not weighed out) and standard sugar samples (D/L-ribose and D/L-glucose, $0.1 \mathrm{mg}$ for each) respectively, were heated with L-cysteine methyl ester $(0.1 \mathrm{mg})$ in pyridine $(400 \mu \mathrm{L})$ in a $2 \mathrm{~mL}$ glass vial at $60^{\circ} \mathrm{C}$ for $60 \mathrm{~min}$, then o-tolyl isothiocyanate $(200 \mu \mathrm{L})$ was added to the reaction mixture and kept at $60^{\circ} \mathrm{C}$ for additional $60 \mathrm{~min}$. Then, the reaction mixture was directly analyzed by LC-ESI-MS (COSMOSIL $5 \mu \mathrm{m}, 4.6 \times 250 \mathrm{~mm}$, $\mathrm{C}_{18}$ column). Analysis was performed at $30{ }^{\circ} \mathrm{C}$ with a flow rate of $1.0 \mathrm{~mL} / \mathrm{min}$, and the elution was carried out using a gradient of $\mathrm{MeCN}\left(0-30 \mathrm{~min}, 10-50 \%\right.$, linear gradient) in $\mathrm{H}_{2} \mathrm{O}$. Source parameters in the positive ion mode were set as follows: Capillary entrance voltage $=-4500 \mathrm{~V}$, end plate offset $=-500 \mathrm{~V}$, nebulizer pressure $\left(\mathrm{N}_{2}\right)=11.6 \mathrm{psi}$, dry gas $\left(\mathrm{N}_{2}\right)=6.0 \mathrm{~L} / \mathrm{min}$, dry gas temperature $=220^{\circ} \mathrm{C}$. High-purity nitrogen $\left(\mathrm{N}_{2}\right)$ were used as the nebulizing gas. Ion Peaks were 
extracted at $m / z 447$ for ribose and at $m / z 471$ for glucose identified by comparison of retention time with those of standards. The retention time of D-ribose and D-glucose derivatives were 22.3 and $21.0 \mathrm{~min}$, respectively.

\subsection{Cytotoxicity Assay}

Cancer cell lines, including 4T1, U937, PC3, HL-60, HT-29, A549, NCI-H460, and K562, were purchased from ATCC. All the cells were maintained in RPMI1640 supplemented with 10\% FBS, 100 units $/ \mathrm{mL}$ Penicillin G and $100 \mu \mathrm{g} / \mathrm{mL}$ streptomycin. All the cancer cells were incubated at $37{ }^{\circ} \mathrm{C}$ in humidified air containing $5 \% \mathrm{CO}_{2}$. MTT assay was used to determine the cell viability. Cells were seeded in 96-well plates at 1.5-3.0 × 10 $/ \mathrm{mL}(100 \mu \mathrm{L} /$ well $)$. After $24 \mathrm{~h}$ incubation, 5 different concentrations (final concentrations were 1.6, 3.1, 6.3, 12.5 and $25.0 \mu \mathrm{M}$ ) of tested compounds were added into the wells in triplicate. Five concentrations of doxorubicin were tested, including 2.0, 1.0, $0.5,0.25$, and $0.125 \mu \mathrm{M}$. Cells were incubated for $96 \mathrm{~h}$ before MTT was added into the cells at a final concentration of $500 \mu \mathrm{g} / \mathrm{mL}$, and the plates were incubated for an additional $4 \mathrm{~h}$. The resultant formazan crystals were dissolved in $200 \mu \mathrm{L}$ of DMSO, then a microplate reader (Synergy HT, Bio-Tek) was used to measure the absorbance of the plates at $570 \mathrm{~nm}$ for testing the cell viability of serial concentrations of compounds and the $\mathrm{IC}_{50}$ were estimated.

\section{Conclusions}

A total of 17 diphenyl ethers, including 6 new compounds, were isolated from a marine-derived Aspergillus sydowii. Compounds $\mathbf{1}$ and $\mathbf{2}$ are rare diphenyl ether glycosides containing a D-ribofuranose moiety. Although natural diphenyl ethers have been extensively investigated, their structures still exhibit variability due to the presence of hydroxy groups, and the diversity and location of sugar moieties. Furthermore, a modified method based on LC-MS analysis was used to determine the absolute configuration of sugar moieties. Comparing to conventional method based on LC-UV, which normally requires $0.5-3 \mathrm{mg}$ of sample [34-37], our method has higher sensitivity due to the use of ESIMS detection, and as low as $0.05 \mathrm{mg}$ of sample was enough to determine the absolute configuration of the sugar units using this procedure. Moreover, all the compounds were evaluated for their cytotoxicity against eight cancer cell lines, and compounds 1, 5, 6, and 8-11 were found to exhibit highly selective cytotoxicities against different cancer cell lines.

Supplementary Materials: The following are available online at http:/ /www.mdpi.com/1660-3397/16/11/451/ s1, Figures S1-S53: HRESIMS, 1D and 2D NMR, IR, and UV spectra of 1-19 and 6a, Figures S54-S56: LC-ESI-MS analysis of sugar derivatives of 1-3, Figure S57: the internal transcribed spacers (ITS) sequence of strain FNA026.

Author Contributions: Y.-N.W., Y.D. and Y.-H.M. conducted most of the isolation, acquirement of NMR spectra, structural determination and the bioactivity evaluation of compounds; Y.W., B.-Y.L., J.B., D.-J.Y. and L.Z. assisted the data analyzes. D.-Q.F. isolated the fungal species, Y.-H.P. and Y.-C.H. designed the experiments and wrote the manuscript. All authors reviewed the manuscript.

Funding: This research was funded by the National Natural Sciences Foundation of China (No. 81522043) and the CAMS Innovation Fund for Medical Sciences (CIFMS, No. 2016-I2M-3-010, 2017-I2M-4-004).

Acknowledgments: We are grateful to the Department of Instrumental Analysis in Institute of Materia Medica, Chinese Academy of Medical Sciences \& Peking Union Medical College for the spectroscopic measurements and J.-B.L. for the HRMS analysis.

Conflicts of Interest: The authors declare no conflict of interest.

\section{References}

1. Hu, Y.; Potts, M.B.; Colosimo, D.; Herrera-Herrera, M.L.; Legako, A.G.; Yousufuddin, M.; White, M.A.; MacMillan, J.B. Discoipyrroles A-D: Isolation, structure determination, and synthesis of potent migration inhibitors from Bacillus hunanensis. J. Am. Chem. Soc. 2013, 135, 13387-13392. [CrossRef] [PubMed]

2. Hu, Y.; Wang, K.; MacMillan, J.B. Hunanamycin A, an antibiotic from a marine-derived Bacillus hunanensis. Org. Lett. 2013, 15, 390-393. [CrossRef] [PubMed] 
3. Song, X.; Xiong, Y.; Qi, X.; Tang, W.; Dai, J.; Gu, Q.; Li, J. Molecular Targets of Active Anticancer Compounds Derived from Marine Sources. Mar. Drugs 2018, 16, 175. [CrossRef] [PubMed]

4. Moghadamtousi, S.; Nikzad, S.; Kadir, H.; Abubakar, S.; Zandi, K. Potential Antiviral Agents from Marine Fungi: An Overview. Mar. Drugs 2015, 13, 4520-4538. [CrossRef] [PubMed]

5. Blunt, J.W.; Carroll, A.R.; Copp, B.R.; Davis, R.A.; Keyzers, R.A.; Prinsep, M.R. Marine natural products. Nat. Prod. Rep. 2018, 35, 8-53. [CrossRef] [PubMed]

6. Bugni, T.S.; Ireland, C.M. Marine-derived fungi: A chemically and biologically diverse group of microorganisms. Nat. Prod. Rep. 2004, 21, 143-163. [CrossRef] [PubMed]

7. Sanchez, J.F.; Somoza, A.D.; Keller, N.P.; Wang, C.C.C. Advances in Aspergillus secondary metabolite research in the post-genomic era. Nat. Prod. Rep. 2012, 29, 351-371. [CrossRef] [PubMed]

8. Peng, J.; Gao, H.; Zhang, X.; Wang, S.; Wu, C.; Gu, Q.; Guo, P.; Zhu, T.; Li, D. Psychrophilins E-H and Versicotide C, Cyclic Peptides from the Marine-Derived Fungus Aspergillus versicolor ZLN-60. J. Nat. Prod. 2014, 77, 2218-2223. [CrossRef] [PubMed]

9. Bladt, T.; Frisvad, J.; Knudsen, P.; Larsen, T. Anticancer and Antifungal Compounds from Aspergillus, Penicillium and Other Filamentous Fungi. Molecules 2013, 18, 11338-11376. [CrossRef] [PubMed]

10. Gong, D.L.; Wang, X.J.; Xiang, Z.D.; Wang, J.D.; Zhang, H.; Liu, C.X.; Zhang, J.; Xiang, W.S. Diphenyl etheric metabolites from Streptomyces sp. neau50. J. Antibiot. 2011, 64, 465-467. [CrossRef] [PubMed]

11. Li, X.; Xia, Z.; Tang, J.; Wu, J.; Tong, J.; Li, M.; Ju, J.; Chen, H.; Wang, L. Identification and Biological Evaluation of Secondary Metabolites from Marine Derived Fungi-Aspergillus sp. SCSIOW3, Cultivated in the Presence of Epigenetic Modifying Agents. Molecules 2017, 22, 1302. [CrossRef] [PubMed]

12. Yurchenko, A.A.; Smetanina, O.F.; Kalinovsky, A.I.; Kirichuk, N.N.; Pivkin, M.V.; Ivanets, E.V.; Yurchenko, E.A.; Afiyatullov, S.S. New Metabolites from a Marine Sediment-Derived Fungus, Aspergillus carneus. Nat. Prod. Commun. 2015, 10, 1247-1250. [PubMed]

13. Wu, Z.; Wang, Y.; Liu, D.; Proksch, P.; Yu, S.; Lin, W. Antioxidative phenolic compounds from a marine-derived fungus Aspergillus versicolor. Tetrahedron 2016, 72, 50-57. [CrossRef]

14. Bunyapaiboonsri, T.; Yoiprommarat, S.; Intereya, K.; Kocharin, K. New diphenyl ethers from the insect pathogenic fungus Cordyceps sp. BCC 1861. Chem. Pharm. Bull. 2007, 55, 304-307. [CrossRef] [PubMed]

15. Shi, T.; Qi, J.; Shao, C.L.; Zhao, D.L.; Hou, X.M.; Wang, C.Y. Bioactive Diphenyl Ethers and Isocoumarin Derivatives from a Gorgonian-Derived Fungus Phoma sp. (TA07-1). Mar. Drugs 2017, 15, 146. [CrossRef] [PubMed]

16. Thadhani, V.M.; Choudhary, M.I.; Andersen, R.J.; Karunaratne, V. Novel entry into 5-decarboxydibenzofurans via Smiles rearrangement of the lichen para-depside, erythrin. J. Chem. Res. 2010, 34, 154-157. [CrossRef]

17. Yang, G.; Yun, K.; Nenkep, V.N.; Choi, H.D.; Kang, J.S.; Son, B.W. Induced production of halogenated diphenyl ethers from the marine-derived fungus Penicillium chrysogenum. Chem. Biodivers. 2010, 7, 2766-2770. [CrossRef] [PubMed]

18. Zhao, D.L.; Shao, C.L.; Zhang, Q.; Wang, K.L.; Guan, F.F.; Shi, T.; Wang, C.Y. Azaphilone and Diphenyl Ether Derivatives from a Gorgonian-Derived Strain of the Fungus Penicillium pinophilum. J. Nat. Prod. 2015, 78, 2310-2314. [CrossRef] [PubMed]

19. Xiao, J.; Hu, J.Y.; Sun, H.D.; Zhao, X.; Zhong, W.T.; Duan, D.Z.; Wang, L.; Wang, X.L. Sinopestalotiollides A-D, cytotoxic diphenyl ether derivatives from plant endophytic fungus Pestalotiopsis palmarum. Bioorg. Med. Chem. Lett. 2018, 28, 515-518. [CrossRef] [PubMed]

20. Wang, J.; Lu, Z.; Liu, P.; Wang, Y.; Li, J.; Hong, K.; Zhu, W. Cytotoxic polyphenols from the fungus Penicillium expansum 091006 endogenous with the mangrove plant Excoecaria agallocha. Planta Med. 2012, 78, 1861-1866. [CrossRef] [PubMed]

21. Peng, W.; You, F.; Li, X.L.; Jia, M.; Zheng, C.J.; Han, T.; Qin, L.P. A new diphenyl ether from the endophytic fungus Verticillium sp. isolated from Rehmannia glutinosa. Chin. J. Nat. Med. 2013, 11, 673-675. [CrossRef] [PubMed]

22. Tian, Y.; Qin, X.; Lin, X.; Kaliyaperumal, K.; Zhou, X.; Liu, J.; Ju, Z.; Tu, Z.; Liu, Y. Sydoxanthone C and acremolin B produced by deep-sea-derived fungus Aspergillus sp. SCSIO Ind09F01. J. Antibiot. 2015, 68, 703-706. [CrossRef] [PubMed] 
23. Lu, Z.; Zhu, H.; Fu, P.; Wang, Y.; Zhang, Z.; Lin, H.; Liu, P.; Zhuang, Y.; Hong, K.; Zhu, W. Cytotoxic polyphenols from the marine-derived fungus Penicillium expansum. J. Nat. Prod. 2010, 73, 911-914. [CrossRef] [PubMed]

24. Zhao, H.; Wang, G.Q.; Tong, X.P.; Chen, G.D.; Huang, Y.F.; Cui, J.Y.; Kong, M.Z.; Guo, L.D.; Zheng, Y.Z.; Yao, X.S.; et al. Diphenyl ethers from Aspergillus sp. and their anti-A $\beta_{42}$ aggregation activities. Fitoterapia 2014, 98, 77-83. [CrossRef] [PubMed]

25. Asami, Y.; Jang, J.H.; Oh, H.; Sohn, J.H.; Kim, J.W.; Moon, D.O.; Kwon, O.; Kawatani, M.; Osada, H.; Kim, B.Y.; et al. Violaceols Function as Actin Inhibitors Inducing Cell Shape Elongation in Fibroblast Cells. Biosci. Biotechnol. Biochem. 2012, 76, 1431-1437. [CrossRef] [PubMed]

26. Camilleri, P.; Weaver, K.; Clark, M.T.; Bowyer, J.R.; Hallahan, B.J. Some Novel Diphenyl Ether Herbicides with Peroxidizing Activity. J. Agric. Food Chem. 1988, 36, 1061-1063. [CrossRef]

27. Serianni, A.S.; Barker, R. [C-13]-Enriched tetroses and tetrofuranosides-An evaluation of the relationship between NMR parameters and furanosyl ring conformation. J. Org. Chem. 1984, 49, 3292-3300. [CrossRef]

28. Gubica, T.; Szeleszczuk, L.; Pisklak, D.M.; Stepien, D.K.; Cyranski, M.K.; Kanska, M. Reliable evaluation of molecular structure of methyl 3-O-nitro-alpha-D-glucopyranoside and its intermediates by means of solid-state NMR spectroscopy and DFT optimization in the absence of appropriate crystallographic data. Tetrahedron 2014, 70, 1910-1917. [CrossRef]

29. Tvaroska, I.; Taravel, F.R. Carbon-proton coupling constants in the conformational analysis of sugar molecules Adv. Carbohydr. Chem. Biochem. 1995, 51, 15-61. [CrossRef]

30. Li, X.B.; Zhou, Y.H.; Zhu, R.X.; Chang, W.Q.; Yuan, H.Q.; Gao, W.; Zhang, L.L.; Zhao, Z.T.; Lou, H.X. Identification and Biological Evaluation of Secondary Metabolites from the Endolichenic Fungus Aspergillus versicolor. Chem. Biodivers. 2015, 12, 575-592. [CrossRef] [PubMed]

31. Tanahashi, T.; Takenaka, Y.; Nagakura, N.; Hamada, N. Dibenzofurans from the cultured lichen mycobionts of Lecanora cinereocarnea. Phytochemistry 2001, 58, 1129-1134. [CrossRef]

32. Liu, S.; Wang, H.; Su, M.; Hwang, G.J.; Hong, J.; Jung, J.H. New metabolites from the sponge-derived fungus Aspergillus sydowii J05B-7F-4. Nat. Prod. Res. 2017, 31, 1682-1686. [CrossRef] [PubMed]

33. Takenaka, Y.; Tanahashi, T.; Nagakura, N.; Hamada, N. Phenyl ethers from cultured lichen mycobionts of Graphis scripta var. serpentina and G. rikuzensis. Chem. Pharm. Bull. 2003, 51, 794-797. [CrossRef]

34. Tanaka, T.; Nakashima, T.; Ueda, T.; Tomii, K.; Kouno, I. Facile discrimination of aldose enantiomers by reversed-phase HPLC. Chem. Pharm. Bull. 2007, 55, 899-901. [CrossRef] [PubMed]

35. Liu, X.; Fu, J.; Yao, X.J.; Yang, J.; Liu, L.; Xie, T.G.; Jiang, P.C.; Jiang, Z.H.; Zhu, G.Y. Phenolic Constituents Isolated from the Twigs of Cinnamomum cassia and Their Potential Neuroprotective Effects. J. Nat. Prod. 2018, 81, 1333-1342. [CrossRef] [PubMed]

36. Kim, B.; Han, J.W.; Ngo, M.T.; Dang, Q.L.; Kim, J.-C.; Kim, H.; Choi, G.J. Identification of novel compounds, oleanane- and ursane-type triterpene glycosides, from Trevesia palmata: Their biocontrol activity against phytopathogenic fungi. Sci. Rep. 2018, 8, 14522. [CrossRef] [PubMed]

37. Wang, L.L.; Hao, L.J.; Zhou, Z.B.; Zhu, X.L.; Shi, Z.H.; Miyamoto, T.; Pan, K. Lycodine-type alkaloids and their glycosides from Lycopodiastrum casuarinoides. Phytochemistry 2018, 154, 63-72. [CrossRef] [PubMed]

(C) 2018 by the authors. Licensee MDPI, Basel, Switzerland. This article is an open access article distributed under the terms and conditions of the Creative Commons Attribution (CC BY) license (http://creativecommons.org/licenses/by/4.0/). 